\title{
The Protection of Debtor Rights on the Stage of Household Credit Agreement Implementation
}

\author{
Marwah $^{1}$ \\ \{marwah@unhas.ac.id $\left.{ }^{1}\right\}$ \\ Faculty of Law, Hasanuddin University, Indonesia ${ }^{1}$
}

\begin{abstract}
This research is an empirical research that aims to know and analyse the protection of the debtor's right in the implementation phase of mortgage loan agreement. One form of state responsibility under Article 28H paragraph (1) of the 1945 Constitution of the Republic of Indonesia is through the implementation of housing and settlement areas so that the people are able to occupy a decent and affordable house in all areas of Indonesia. In order to help the government program, the banks offer mortgage loans. In the implementation phase of the mortgage agreement, the debtor's obligation to pay the debt is an obligation that must be implemented based on the agreed agreement. Based on the results, the determination of interest applied by banks in Indonesia is a combination of fixed rate and floating rate method. So, at the beginning of the credit, the bank offers a rate below $10 \%$ every year for a period of one to five years (fixed rate). However, after the fixed rate interest expires, the bank is entitled to fix the interest rate increase. By the time the floating rate interest is in effect, some borrowers are aware that the interest charged by the bank is larger than expected because the number of credit instalments suddenly increased without any notice from the bank. This causes some debtor customers to be unable to pay credit instalments.
\end{abstract}

Keywords: Debtor's Right; Implementation; Government Program.

\section{Introduction}

Credit in banking activities is the most important business activity because the largest income from a bank's business comes from income from business credit activities in the form of interest and fees. The scope of credit is not only in the form of lending funds to debtor customers, but also related to elements that include sources of credit funds, fund allocation, credit organization and management, credit policies, credit administration and documentation, credit supervision and settlement of non-performing loan. ${ }^{1}$ Therefore, credit business requires professional handling with high moral integrity. Credit activities will be smooth if the parties involved in the activity trust each other. This condition is needed by banks in the business and the allocation of funds for credit because the funds in the bank are mostly third-party funds entrusted to the bank.

When the bank and prospective debtor have signed a credit agreement, the credit agreement is binding on both parties and acts as a law for both parties. ${ }^{2}$ The enactment of the agreement as a law for those who bind themselves to an agreement has placed the agreement

${ }_{1}^{1}$ Muhamad Djumhana, 2011, Hukum Perbankan di Indonesia, Citra Aditya Bakti, Bandung, p. 365

${ }^{2}$ Article 1338 par. 1 Burgerlijk Wetboek (BW) 
as law. In this case Roscoe Pound argues that the balance of protection between producers and consumers reveals the legal function as a means of social control, namely controlling the life of society by balancing the interests that exist in society. ${ }^{3}$

Furthermore, according to P.S. Atiyah, the contract has three basic objectives, namely: ${ }^{4}$

a. It is inspired by the desire to enforce promises and to protect the reasonable expectations which are generated both of promises and by other forms of conduct;

b. Contract law itself is also powerfully influenced and affected by the idea that unjust enrichment should not be permitted;

c. Contract law is also designed to prevent certain kinds of harm, particularly harm of an economic nature, or at least to compensate those who suffer such harm.

Based on the provisions of Article 1320 Burgerlijk Wetboek (BW), that there are four legal conditions for an agreement, namely agreeing to those who bind themselves, the ability to make an engagement, a certain thing, and a lawful reason. Regarding the agreement as a legal requirement of the agreement, based on the provisions of Article $1321 \mathrm{BW}$, that if an agreement is reached due to an oversight regarding the nature of the goods that are the subject of the agreement or due to coercion or fraud, then there is no agreement. Thus, the agreement must occur in a state of free and honest parties, no fraud, no coercion and no oversight.

In the practice of lending by banking institutions, especially KPR, at first some banks offered quite competitive interest, which was below $10 \%$ per year for a period of one to five years (fixed rate). However, according to the agreement that has been made, after the fixed rate period ends, the bank has the right to unilaterally increase interest rates. ${ }^{5}$ In addition, several KPR debtor customers also objected to the method of annuity mortgage interest charges used by the bank at this time. In the annuity method, the total instalments each month for one year will be the same, while the principal and interest instalments will change. The principal instalments will increase every year and interest instalments will decrease. ${ }^{6}$ The interest charged with annuity method is very much affected by the mortgage for a period of 10 to 15 years because when the debtor customer wants to repay a part or all of the loan before the mortgage agreement expires, the principal amount to be paid is still very high.

The lawsuit regarding objections regarding the interest rate of the mortgage in floating with the annuity interest calculation, was once filed by Elman Simangunsong as the Plaintiff domiciled in Medan, against PT. Bank Tabungan Negara (Persero) as Defendant, arrived at the cassation level at the Supreme Court with case register No. 2644 K/Pdt/2012. In the case, it was explained that between the Plaintiff and the Defendant had entered into a KPR Agreement on October 20, 2009, with a principal amount of IDR 108,000,000.00 and a credit period of 120 months. The interest rate set in the KPR is $13.5 \%$ per year, with an annuity interest charging system, so that the instalment that must be paid by the Plaintiff is IDR $1,691,900.00$ per month. Based on the mortgage agreement signed by the Plaintiff and Defendant, the due date of the mortgage loan instalment is on the 7 th of each month, and the

\footnotetext{
${ }^{3}$ Ahmadi Miru, 2013, Prinsip-prinsip Perlindungan Hukum Bagi Konsumen di Indonesia, RajaGrafindo Persada, Jakarta, p. 64

${ }^{4}$ P.S. Atiyah, 1995, An Introduction to the Law of Contract, Oxford University Press: New York, p. 35

${ }^{5}$ Research Results, November 29, 2017

${ }^{6}$ Ismail, 2010, Manajemen Perbankan dari Teori Menuju Aplikasi, Kencana, Jakarta, p. 143
} 
fine in arrears is $1.5 \%$ per month, and the expedited payment penalty is $1 \%$ of the remaining loan principal.

In the case it was explained that between the Plaintiff and the Defendant had entered into a KPR Agreement on October 20, 2009, with a credit ceiling amounting to IDR $108,000,000.00$ and a credit period of 120 months. The amount of interest set in the KPR is $13.5 \%$ per year, with an annuity interest charging system, so that the instalment to be paid by the Plaintiff is IDR 1,691,900.00 per month. Based on the KPR Agreement signed by the Plaintiff and Defendant, the due date of the mortgage loan repayment is on the 7th of each month, and the arrears fine is $1.5 \%$ per month, and the expedited payment penalty is $1 \%$ of the remaining credit principal. ${ }^{8}$

In the lawsuit, the Plaintiff objected to the method of calculating payments between the difference in repayment of principal debt and very large interest payments, so that the Plaintiff stopped paying the instalments before the calculation of interest and payment of principal debt was calculated in a balanced and proportionate manner. In this case the plaintiff has paid 8 months in instalments amounting to IDR 13,971,955.00 but the Plaintiff's remaining credit principal is based on the checking account on June 7, 2010, which is IDR 107,618,645.00. Therefore, according to the Defendant, the annuity interest calculation system has violated the law, the principle of propriety and the principle of balance in the exercise of freedom of contract.

In the cassation memory, the Plaintiff stated that the Medan District Court had erroneously applied the law of proof in its legal considerations which rejected the Plaintiff's claim entirely in decision No. 291/Pdt.G/2010/PN.Mdn on February 8, 2011, which was further strengthened by the Medan High Court with decision No. 152/PDT/2011/PT-MDN on July $8,2011{ }^{9}$ At the cassation level, in the consideration the consideration, the Supreme Court judge argued that the reasons for the cassation from the Plaintiff could not be justified because the consideration in the Medan High Court ruling affirming the Medan District Court ruling was correct where the Plaintiff could not prove the claim of the claim that the imposition of interest and the principal debt instalment by the Defendant against the Plaintiff is against the law, while the Defendant can prove his denial argument that the Defendant's action in the a quo case is in accordance with a legally made credit agreement between the Plaintiff and the Defendant.

\section{Research Method}

This research is an empirical legal research. This method is used to analyse the position of the balance principle at the stage of implementing a mortgage agreement between the bank and debtor customers. Data obtained from primary data and secondary data in this study were analysed with qualitative techniques then presented descriptively, namely by examining the existing problems and then concluding them synchronously, systematically and scientifically as shown through factual data exposure.

\footnotetext{
${ }^{7}$ Directory of Decisions of the Supreme Court of the Republic of Indonesia Number: 2644/Pdt/2012, accessed at http://putusan.mahkamahagung.go.id, on June 9, 2016.

${ }^{8}$ Ibid.

${ }^{9}$ Ibid.
} 


\section{Results and Discussion}

At the implementation stage of the mortgage agreement, the debtor's obligation to pay debts is an achievement that must be carried out based on the form of achievement as stipulated in the provisions of Article $1234 \mathrm{BW}$. This is affirmed in the provisions of Article $1235 \mathrm{BW}$, which contains the rule that in each engagement to provide something is the obligation of the debtor to submit the material concerned and to care for him as a good father of the house, until the time of submission. Furthermore, based on the provisions of Article $1236 \mathrm{BW}$, it is stipulated that the debtor is obliged to compensate the cost, loss, and interest to the debtor, if he has brought himself unable to give up his material, or has not properly cared for to save him.

In the KPR Agreement, the obligation to provide protection in order to achieve a balance of rights and obligations of the parties, is not only the obligation of the government but also as an obligation of parties who have stronger economic capacity. The provision of protection by those who have stronger economic capacity to the weak economy indicates that there is a good will of the strong economy parties in formulating an agreement. Likewise, the weak economy also has an obligation to provide protection to strong economic parties in terms of protecting the security of the strong economy of the capital disbursed to it. The principle of balance of work which has imperative meaning, forces the parties to submit to the agreement so as to make the balance as a principle of law in an agreement. ${ }^{10}$ Therefore, the existence of an unbalanced position and / or bargaining position in the credit agreement is contrary to the purpose of law, namely justice, because the agreement is formed as a forum that brings the interests of the parties together as a form of fair exchange of interests.

According to Nieuwenhius, fulfillment of achievement as an embodiment of the implementation of contractual obligations other than determined by autonomous factors (what is determined by the parties to the contract), is also determined by factors outside the parties (heteronomous factors). Therefore, in analysing the binding power of a contract that is related to the implementation of contractual obligations, it is necessary to consider the factors that determine the contents of the contract, namely autonomous factors and heteronomous factors. $^{11}$

Autonomous factors, known as "party autonomy" (partij autonomie) is the main factor or "primary determinant" in determining the contents of the contract, meaning that the nature and extent of the rights and obligations of the parties to the contract can be seen in what they agree on. As a primary determinant factor, autonomous factors occupy a hierarchy or main sequence to determine the binding power of a contract. The foundation of the idea that autonomous factors are the primary determinants that originate in the parties, as affirmed in Article 1338 (1) BW, that all agreements made legally apply as laws for those who make them. Under the provisions of Article 1338 (1) BW a contract has binding power, provided that the contract is made legally. That is, in the formation of the contract must pay attention to the validity of the contract as stipulated in Article $1320 \mathrm{BW}, 1335 \mathrm{BW}$, and $1337 \mathrm{BW} .^{12}$

If the autonomous factor comes from the parties themselves (partij autonomie), to jointly determine the nature and extent of rights and obligations of the parties, on the contrary,

${ }^{10}$ Herlien Budiono, 2006, Asas Keseimbangan Bagi Hukum Perjanjian Indonesia, Citra Aditya Bakti, Bandung, p. 76

${ }^{11}$ Agus Yudha Hernoko, 2011, Hukum Perjanjian, Asas Proporsionalitas dalam Kontrak Komersial, Kencana Prenada Media Group: Jakarta, p. 244

${ }^{12}$ Ibid, p. 245 
heteronomous factors are factors that are sourced from outside the parties. Heteronomous factors are "subsidair determinants" that occupy a hierarchy or sequence after autonomous factors to determine the binding power of a contract. ${ }^{13}$

Heteronymic factors can be traced to the formulation of Article $1339 \mathrm{BW}$, which places the nature of the contract, propriety, habits, and laws as elements. Meanwhile, another article that can be referred to elaborate heteronomous factors in the contract is Article $1347 \mathrm{BW}$, which contains the rules that the conditions that are always agreed upon according to custom, must be considered to have been included in the contract, even if not explicitly included in the contract. The formulation of Article $1347 \mathrm{BW}$ is related to the conditions normally agreed upon (bestandig gebruikelijk beding) which also relates to the nature of the contract as referred to in Article 1339 BW. Therefore, it is appropriate if the two articles are placed as heteronomous factors (the determinant factor of subsidair) that determines the binding power of a contract. Thus, if we look at the formulation of Article $1339 \mathrm{BW}$ and $1347 \mathrm{BW}$, the heteronomous factor which is the determinant factor of subsidair to determine the binding power of a contract consists of the usual conditions agreed upon (bestandig gebruikelijk beding, compliance, customs, and laws). ${ }^{14}$

It should also be emphasized that it is appropriate for an agreement, including the mortgage agreement, to be fulfilled by both parties in good faith. Good faith (goeder trouw) it is important to prioritize, even in terms of agreements with coercive rules (dwingend recht). In addition, it should also be considered also changes in circumstances that affect the fulfilment of the agreed achievements. ${ }^{15}$

The goodwill of the parties in a mortgage agreement is reflected in the actions of the parties. Based on the agreed mortgage agreement, the debtor customer is obliged to pay the instalments on time. However, when there is an increase in interest rates and instalments, the bank does not submit information about the changes to debtor customers. This causes some debtor customers not to provide sufficient balance for instalment payments in their accounts. In fact, in the mortgage agreement that has been agreed upon, the address and telephone number of the debtor's customer have been listed to facilitate communication.

Regarding information by banks to KPR debtor customers, regarding the increase in interest rates and the number of instalments when the fixed rate interest has expired, can be seen in the following table:

Table 1. Submission of Information about Increase in Interest and Amount of Instalment Loan

\begin{tabular}{cccc}
\hline \multirow{2}{*}{ No. } & \multirow{2}{*}{ Bank Name } & \multicolumn{2}{c}{ Information Submission } \\
\cline { 3 - 4 } & & Yes & No \\
\hline 1. & Bank Tabungan Negara & - & 10 \\
\hline 2. & Bank Rakyat Indonesia & - & 10 \\
\hline 3. & Bank Mandiri & - & 10 \\
\hline 4. & Bank Central Asia & 10 & - \\
\hline 5. & Bank Panin & - & 10 \\
\hline & Total & 10 & 40 \\
\hline
\end{tabular}

Source: Primary Data, processed 2018

${ }^{13}$ Ibid.

${ }^{14}$ Ibid, p. 246

${ }^{15}$ Herlien Budiono, 2006, Op.Cit., p. 354 
Based on the data in the table, it is known that 4 of the 5 banks that were sampled in this study did not submit information about the increase in interest and the amount of mortgage loan installments, before the fixed rate interest expired. Whereas 1 bank, namely Bank Central Asia, has sent via sms to debtor customers, regarding information about the increase in interest and the amount of mortgage loan instalments before the fixed rate interest expires.

Furthermore, good faith aspects are important to be put forward in completing the balance study in the implementation of the KPR Agreement, assuming that the differences in the parties' position in the KPR Agreement are not absolute to make the KPR Agreement biased and detrimental to one party if each party has good intentions to submit in the agreement he made. In this case, Setiawan is of the opinion that the principle of freedom of contract now no longer appears in its full form, partly due to the influence of the determination of the intention both in the pre-contractual, contractual and contractual obligations. ${ }^{16}$

In the implementation of the agreement, good faith is defined as propriety, namely an assessment of the actions of a party in terms of carrying out what has been promised. Good faith at the time of exercising the rights and obligations arising from a legal relationship or agreement is nothing more than good faith when carrying out a legal relationship or agreement that has been made. Therefore, the good intentions actually lie in the inner heart of humans which is reflected in the actual actions of the agreement which will provide an objective measure of whether or not there is a good faith. ${ }^{17}$ If the parties share the same intention in binding themselves in an agreement, the implementation will proceed as expected and the purpose of the agreement can be achieved.

Although good faith in the implementation of the contract has become the most important principle in the contract, it still leaves a number of controversies or problems. According to Ridwan Khairandy, there are at least three issues related to good faith. First, understanding good faith is not universal. Second, the legal test used by the judge to assess whether there is good faith in the contract. Third, the understanding and attitude of the courts in Indonesia are related to the good faith function in the implementation of the contract. ${ }^{18}$

It should be noted that goodwill does not only refer to the good will of the parties, but must also refer to the values that develop in the community, because good faith is part of the community. This good faith ultimately reflects the standards of justice or public decency. With such meaning, good faith is used as a standard as a universal social force that regulates social relations, namely every citizen must have an obligation to act in good faith towards all citizens. Thus, if someone acts in good faith in accordance with objective standards based on social habits, then others must act similarly to themselves. ${ }^{19}$

This is an objective conception that is universally applied in all transactions, and in accordance with the Roscoe Pound postulate, that: "Men must be assume that those with whom they deal in general intercourse of society will act in good faith and will carry out their undertaking according to the expectation of the community". ${ }^{20}$

Standards or tests for good faith in the implementation of contracts are certainly objective standards. In contract law, the notion of acting in good faith refers to compliance with a reasonable commercial standard dealing deal, which according to the Dutch legislator, acts in accordance with redelijkheid en billijkheid (reasonableness and equity). This is indeed an

${ }^{16}$ Setiawan, 2008, Aneka Masalah Hukum dan Hukum Acara Perdata, Alumni, Bandung, p. 179

${ }^{17}$ Djoni S. Gazali and Rachmadi Usman, 2012, Hukum Perbankan, Sinar Grafika, Jakarta, p. 343

18 Ridwan Khairandy. 2014. Hukum Kontrak Indonesia dalam Perspektif Perbandingan (Bagian Pertama), FH UII Press: Yogyakarta, p. 123-124

${ }^{19}$ Ibid., p. $128-129$

${ }^{20}$ Ibid. 
objective standard because one party may not act in an unreasonable and improper way, it will not be a good defence to say that honestly, his conduct is to be reasonable and inequitable. ${ }^{21}$

Furthermore, according to Ridwan Khairandy, good faith has three functions in contract law. The first function teaches that all contracts must be interpreted according to good faith, the second function is the add function, and the third function is the function of limiting and eliminating. ${ }^{22}$

Associated with the first function, that the principle of good faith plays an important role in the interpretation of contracts, in the past held the opinion of both scholars and legislation that the interpretation of contracts is only needed for something that is not clear. If the contents of the contract are clear, then no interpretation or interpretation is needed. In connection with this Article 1342 BW (old) the Netherlands determines that if the words of a contract are clear, it is not permissible to deviate from it by means of interpretation. In the current development, it is understood that in the interpretation of the contract there is no distinction between the contents of the contract that is clear and unclear, even to the words that are clear, can be interpreted by directing it to the wishes of the parties or special conditions relevant to the formation of meaning referred to by the parties. ${ }^{23}$

However, unlike BW (old), BW (new) Netherlands no longer contains contract interpretation provisions. The contractual interpretation provisions contained in the BW (old) are omitted because some are deemed unnecessary and some are considered too general in their formulation, so that their meaning is not correct. Thus, this interpretation is entirely handed over to the world of justice and science to develop provisions and principles in the interpretation of contracts. ${ }^{24}$

In its second function, good faith can add to the contents of a particular agreement and can also add to the words of the provisions of the law concerning the agreement. This function can be applied if there are rights and obligations arising between the parties not expressly stated in the contract. ${ }^{25}$ Furthermore, in the third function of good faith which is limiting and negating, some pre-war legal experts argue that good faith also has that function. They teach that a certain agreement or a certain condition in the contract or the provisions of the law concerning the contract can be ruled out, if since the contract is made, the situation has changed so that the implementation of the contract creates injustice. In such circumstances, contractual obligations can be restricted, even completely eliminated on the basis of good faith. $^{26}$

In the implementation phase of the KPR Agreement, there may be a "certain situation" that is not as usual so that the balance of the gain from the agreement is not achieved. Certain conditions can be in the form of, only one party that gains profits and the other party experiences a loss so that there is no balance in the implementation of the agreement. Therefore, the mortgage agreement can be considered fair if both parties as a result of the agreement are in a more favourable position than before the agreement was made. ${ }^{27}$

Thus, it does not matter how much profit the two parties get or the balance of profits obtained. In essence, there are advantages gained by each party and the satisfaction of each party for the benefits it receives. In such a case, balance must not necessarily be based on the

${ }^{21}$ Ibid., p. 135

${ }^{22}$ Ibid., p. 144

${ }^{23}$ Ibid.

${ }^{24}$ Ibid., p. 145

${ }^{25}$ Ibid., p. 146

${ }^{26}$ Ibid., p. 146-147

${ }^{27}$ Herlien Budiono, Op. Cit., p. 351 
calculation of profit and loss in the material sense, but also fulfilling all the objectives of the contract, especially the achievement of immaterial existence. Balance in the KPR Agreement, can also be interpreted as a harmonious reciprocal relationship in the form of each party performing a balanced achievement against the other party. ${ }^{28}$ If the debtor customer cannot return the loan or debt, then the balance in the implementation of the mortgage agreement is certainly not yet achieved.

Responding to this matter, Mariam Darus Badrulzaman stated that the principle of balance is a continuation of the principle of equality, giving the creditor the right to demand repayment of achievements through the wealth of the debtor, and also giving the creditor the obligation to carry the burden of carrying out the agreement in good faith. In a state of strong creditor position, it is balanced with its obligation to pay attention to good faith, make the position of creditors and debtors balanced. ${ }^{29}$ For this reason, it is necessary to create a favourable and friendly bank credit agreement climate, avoid pressure and coercion and prioritize negotiations to protect each other's interests and seek balance of interests. The application of such conditions is the application of the principle of balance in the bank credit agreement, including the KPR Agreement.

The legal consequences of an imbalance in a credit agreement, including the mortgage agreement, which can result in the credit agreement can be cancelled or become null and void. The cancellation of a bank credit agreement can be interpreted in two meanings, namely the bank credit agreement is cancelled in full, or only cancellation of the bank credit agreement clause containing only exoneration clause. In this case, BW does not provide explicit references regarding the purpose of cancelling an agreement. As a result, this lack of clarity gives the judge the authority to interpret the intention of "cancelling an agreement", so that there are differences in interpretation by several judges.

From various literatures, in general the meaning of cancelling is aimed at cancelling the agreement in full, but in various cases, the cancellation of the credit agreement is directed at cancelling the clause which burdened the debtor's customers only. In this case, the author agrees with the views of some judges who state that the cancellation of the credit agreement must be interpreted as the cancellation of the exoneration clause only.

In court practice, exoneration clauses are often used as a basis for lawsuits, namely to declare a mortgage agreement null and void due to the absence of a balance of rights and obligations of the parties to the credit agreement. One of the cases referred to is the Supreme Court Decision No. $2644 \mathrm{~K} / \mathrm{Pdt} / 2012$ which resolved the lawsuit filed by Elman Simangunsong as an appeal applicant, against PT. Bank Tabungan Negara, as the researcher described earlier in the introduction.

Based on this, it can be seen that the cancellation of the exoneration clause in the KPR Agreement makes the agreement still valid and cancellation only during the exoneration clause. The consequence is that debtor customer debts remain and debtor customers are still required to pay off debt. Therefore, with the cancellation of the exoneration clause only, the purpose of the KPR Agreement can be redirected to the original goal, ie each party obtains profits from the agreement. This is certainly in accordance with the fact, that the parties that are bound in a mortgage agreement are parties who need each other and must complement each other.

The fact of the emergence of claims regarding credit agreements between debtor customers and the bank shows that the public is increasingly aware of its weak position in a

${ }^{28}$ Ibid., p. 349

${ }^{29}$ Mariam Darus Badrulzaman, 2005, Aneka Hukum Bisnis, Alumni, Bandung, p. 42 
credit agreement at the bank. In response to this, in order to protect financial service sector customers, including KPR debtor customers, the OJK has now issued Circular Number 13/SEOJK.07/2014 concerning the Standard Agreement which regulates among others the format of standard agreements and clauses prohibited in the standard agreement.

This is in line with Phil Harris's view that "About Legislative intervention and the solution to the consumer problem, this enormous gap between the theory of contractual freedom and equality, and the reality of modern consumer transactions, has been bridged only relatively recently by state intervention through consumer protection legislation and, to an extent, by an increased sense of 'consumer awareness' by many trading concerns". ${ }^{30}$

This arrangement is an initial milestone for the balance in positioning the parties in an agreement. The phenomenon in the credit agreement at the bank needs to be addressed by the Republic of Indonesia Supreme Court through the provision of its opinions through decisions especially regarding the application/use of the principle of balance in the mortgage agreement. In order to realize legal justice, judges can enter into the realm of the agreement and can set aside the contents of the agreement by exploring, following and understanding the legal values and sense of justice that lives in society according to the mandate of Article 5 paragraph (1) Law of the Republic of Indonesia Number 48 Year 2009 on Judicial Power.

In relation to the description, Herlien Budiono expressed his views regarding efforts to restore balance in an agreement, which includes:

a. Renegotiation, the parties can restore the balance of the agreement that was previously disturbed by re-adjusting or cancelling the agreement after renegotiation. Re-negotiation in order to improve the agreement can be done through peace (schikking), mediation, or by the intervention of a judge. Renegotiation is intended as an effort to restore balance by encouraging the parties to provide new content to the agreement. ${ }^{31}$

b. Adjustment, recovery of balance in an agreement can be pursued through a number of adjustments, such as, cancellation of the agreement as a whole, various cancellations for some, adjustments on court orders or off-court adjustments in the form of cancellations in part due to changing circumstances. ${ }^{32}$

c. Termination of agreement with fulfilment of cancellation or cancellation conditions, and cancellation.

Listening to the description, an illustration is obtained that the principle of balance is very instrumental in implementing an agreement, including the mortgage agreement. The realization of the value of justice can be achieved by increasing the protection of debtor customers because of the position of the bank as a provider of mortgage facilities, always considered stronger than the position of debtor customers who apply for KPR. Regarding the protection of debtor customers, this has generally been regulated in the UUPK and in particular has also been regulated in the OJK Law, which is then set forth in the form of OJK Regulation Number: 1/POJK.07/2013 on Consumer Protection in the Financial Services Sector.

${ }^{30}$ Phil Harris, 2007, An Introduction to Law: Seventh Edition, Cambridge University Press, New York, p. 369

${ }^{31}$ Herlien Budiono, Op. Cit., p. 488

${ }^{32}$ Ibid., p. 491 


\section{Conclusion}

The protection of debtor rights at the stage of implementing a mortgage agreement has not been achieved because the mortgage agreement still includes several clauses that are contrary to Article 22 of the Financial Services Authority Regulation No. 1/POJK/2013 concerning Consumer Protection in the Financial Services Sector. The clause, among others, is that banks can sell land and buildings that are collateral both under hand and auction to other parties to settle obligations without the approval of debtor customers, the bank can review and change the loan interest rate with or without prior notification to debtor customer, as well as authorizing the bank to make corrections to the checking account and be released from all compensation in the form of anything related to the mistake.

\section{References}

[1] Agus Yudha Hernoko. 2011. Hukum Perjanjian, Asas Proporsionalitas dalam Kontrak Komersial, Kencana Prenada Media Group: Jakarta.

[2] Ahmadi Miru. 2013. Prinsip-prinsip Perlindungan Hukum Bagi Konsumen di Indonesia, RajaGrafindo Persada: Jakarta.

[3] Djoni S. Gazali and Rachmadi Usman. 2012. Hukum Perbankan, Sinar Grafika: Jakarta.

[4] Herlien Budiono. 2006. Asas Keseimbangan Bagi Hukum Perjanjian Indonesia, Citra Aditya Bakti: Bandung.

[5] Ismail. 2010. Manajemen Perbankan dari Teori Menuju Aplikasi, Kencana: Jakarta.

[6] Mariam Darus Badrulzaman. 2005. Aneka Hukum Bisnis, Alumni: Bandung.

[7] Muhamad Djumhana. 2011. Hukum Perbankan di Indonesia, Citra Aditya Bakti: Bandung.

[8] Phil Harris, 2007, An Introduction to Law: Seventh Edition, Cambridge University Press: New York.

[9] P.S. Atiyah, 1995, An Introduction to the Law of Contract, Oxford University Press: New York.

[10] Ridwan Khairandy. 2014. Hukum Kontrak Indonesia dalam Perspektif Perbandingan (Bagian Pertama), FH UII Press: Yogyakarta.

[11] Setiawan. 2008. Aneka Masalah Hukum dan Hukum Acara Perdata, Alumni, Bandung. 